\title{
Phenology and seed germination behaviours of some wetland macrophytes at Biratnagar, Nepal
}

\author{
Bhabindra Niroula* and Praju Panta \\ Department of Botany, Post Graduate Campus, T.U., Biratnagar, Nepal \\ *E-mail:niroulab@gmail.com
}

\begin{abstract}
Phenology, seed morphology, seed viability and germination behabiour of some wetland plants in control at moist filter paper in petridishes was carried out in wetland plants-Aeschynemone asper L. (Fabaceae); Eragrostis unioloides (Retz.) Nees exsteudel (Poaceae); Hygrophila auriculata (K. Schum) Heine (Acanthaceae); Pesicaria barbatum (L.) Hara (Polygonaceae); and Rumex dentatus L. (Polygonaceae) were studied at Biratnagar. Number of seeds per gram ranged between161-12722. Viable seeds of $A$. asper (98\%) and P. barbatum (55\%) had no germination but $E$. unioloides had cent percent germination; $H$. auriculata, and Rumex dentatus showed $96 \%$ germination. A.asper and E. unioloides germinated in early rainy; spent vegetative phase up to August- September; and completed flowering, fruiting and seed maturation before winter.
\end{abstract}

Key words: Phenology, seed germination, viability, wetland.

\section{Introduction}

Wetlands are one of the most productive ecosystems and essential life support system with a wide array of benefits (Mitch \& Gooselink, 2000). Abundance of aquatic plants is valuable characteristics of a wetland and constitutes a prominent part of aquatic ecosystems. They provide free service to mankind and play significant role in socioeconomy and culture. In Nepal, 25 ethnic groups mostly from Terai are entirely depends on wetlands (Bhandari, 2009). Wetlands are most threatened and disappearing at an alarming rate (IUCN/Nepal, 1992). They are being lost to agriculture, human settlement and urbanization and pollution from domestic, industrial sewage and agricultural run-offs. Invasive weeds Eichhornia crassipes, Alternanthera philoxeroides, Ipomoea carnea and Mikania micrantha are adversely affecting wetland habitats (Tiwari et al., 2005)

Seed is a device for the reproduction, multiplication, preservation and perpetuation. Phenology provides information on different lifecycle phases of plants in relation to different periods of a year. A record on different phenophases and seed characteristics is a basic step for long term management, conservation and restoration strategy for wetlands (Lal et al. 1997; Niroula \& Kafle 2016; Paudel, 2016; Panta 2016). The present paper aims to communicate the phenology, seed morphology, viability and germination behaviour of some wetland plants of Biratnagar.

\section{Materials and Methods}

Seeds of Aeschynemone asper L. (Fabaceae); Eragrostis unioloides (Retz.) Nees exsteudel (Poaceae); Hygrophila auriculata (K. Schum) Heine (Acanthaceae); Pesicaria barbatum (L.) Hara (Polygonaceae); and Rumex dentatus L. (Polygonaceae) were collected from 
mature and healthy single plant population from wetlands of Biratnagar area, eastern Nepal. They were dried in shade for 7 days and stored in air tight plastic containers at ambient room conditions. Seed morphology (length, breadth) was determined using millimeter scale and colour and shape by visual observation. Number of seeds per gram was determined with electric balance with adequate replicates. Phenology of the plants such as germination/sprouting, vegetative phase, flowering, fruiting, seed maturation and senescence were recorded by field visit at fortnightly intervals following Lodhiyal et al. (1998). Seed viability was recorded by Tetrazolium salt GR, TTC (Triphenyletetrazolium Chloride test (Gasper \& Nagy, 1981). Fresh seeds were tested in petridishes (dia 8.6) for germination in double layered moist filter paper in the laboratory (temperature $26 \pm 4{ }^{\circ} \mathrm{C}$ ). A seed was considered germinated when radicle had broken the pericarp.

\section{Study site}

Biratnagar is located at Lat. $26^{0} 23^{\prime} 10^{\prime \prime}$ to $26^{\circ} 30^{\prime} 49^{\prime \prime} \mathrm{N}$; Long. $87^{0} 14^{\prime} 27^{\prime \prime}$ to $87^{0} 18^{\prime} 29^{\prime \prime} \mathrm{E}$; Alt. $72 \mathrm{msl}$ in Terai plain of eastern Nepal. The climate is tropical and monsoon. There are three distinct seasons viz. rainy (July-October), winter (November-February) and summer (March-June). Soil is alluvial and loamy in texture (sand 40\%, silt $40 \%$, clay 20\%). The average $\mathrm{pH}$ of the soil $(0-10 \mathrm{~cm}$ depth) is 6.5 . Average meteorological data indicate 1225 , 5, and $188 \mathrm{~mm}$ rainfall; $25,10.4$ and $19.60 \mathrm{C}$ minimum air temperature; 32.2, 25 and 33.6 OC maximum air temperature; and $6,3.8$ and $7.3 \mathrm{~km} / \mathrm{h}$ wind speed during rainy, winter and summer season, respectively for the last five years. Average monthly day length (h) of the site is given in Figure 1.

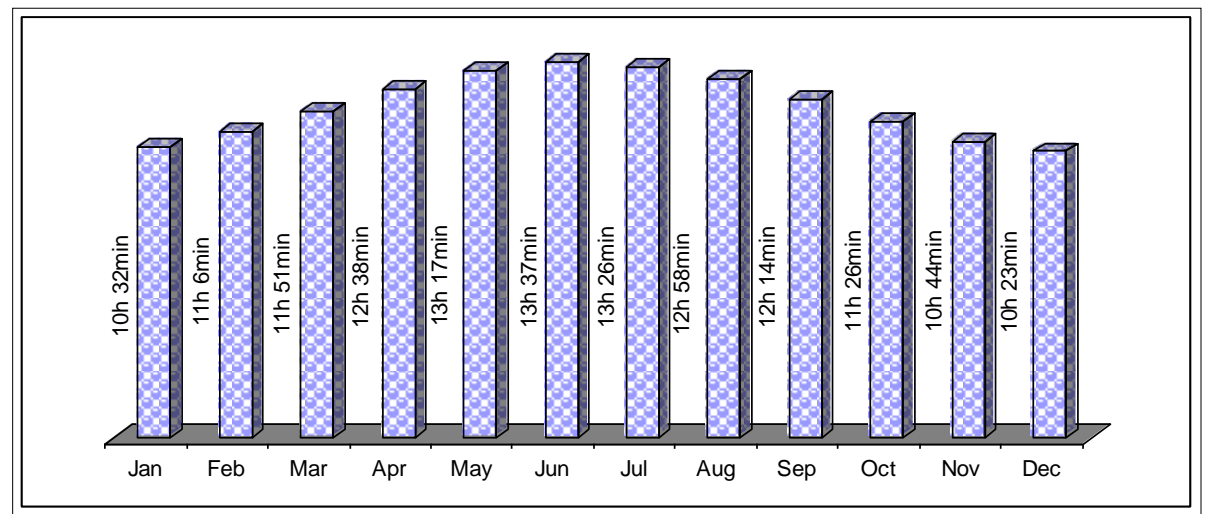

Figure 1. Average monthly day length at Biratnagar.

\section{Results and Discussion \\ Seed characteristics}

Seed colour, shape, length $(\mathrm{mm})$, breadth $(\mathrm{mm})$, size index, shape index and number of seed per $\mathrm{g}$ of wetland plants are given in Table 1. Number of seeds per $\mathrm{g}$ ranged between161-12722. A. asper had minimum and E. unioloides had maximum number representing largest and smallest size of seeds, respectively (Figs 2-7). Seeds of A. asper was kidney shaped, brown- black in colour and E. unioloides was oval in shape and brown in colour. Mikania micrantha cypsela were dark brown rod shaped with ridges and number of seeds per g ranged between 7550-925 (Niroula \& Kafle, 2016). Spilanthu iabadicensis seeds had black colour, obovate shape with 11662 cypsela per g (Paudel, 2016). 
Table 1. Seed characteristics of aquatic macrophytes (mean \pm SE).

\begin{tabular}{llllcccc}
\hline Species & Colour & Shape & $\begin{array}{c}\text { Length } \\
(\mathbf{m m})\end{array}$ & $\begin{array}{c}\text { Breadth } \\
(\mathbf{m m})\end{array}$ & $\begin{array}{c}\text { Size } \\
\text { Index(l/b) }\end{array}$ & $\begin{array}{c}\text { Shape } \\
\text { Index(l×b) }\end{array}$ & Seeds/g \\
\hline $\begin{array}{l}\text { Aeschynemone } \\
\text { asper }\end{array}$ & $\begin{array}{l}\text { Brownish } \\
\text { black }\end{array}$ & Kidney & $2.6 \pm 0.3$ & $1.8 \pm 0$ & 1.5 & 4.8 & $161 \pm 18$ \\
\hline $\begin{array}{l}\text { Eragrostis } \\
\text { unioloides }\end{array}$ & Brown & Oval & $0.7 \pm 0.02$ & $0.4 \pm 0$ & 1.9 & 0.3 & $12772 \pm 327$ \\
\hline $\begin{array}{l}\text { Hygrophila } \\
\text { auriculata }\end{array}$ & $\begin{array}{l}\text { Browinish } \\
\text { grey }\end{array}$ & Obovate & $2.8 \pm 0.3$ & $1.8 \pm 0.02$ & 1.6 & 5.2 & $745 \pm 9.3$ \\
\hline $\begin{array}{l}\text { Pesicaria } \\
\text { barbatum }\end{array}$ & $\begin{array}{l}\text { Brownish } \\
\text { black }\end{array}$ & Ovate & $2.3 \pm 0.03$ & $1.5 \pm 0.01$ & 1.5 & 3.7 & $496 \pm 5.9$ \\
\hline $\begin{array}{l}\text { Rumex } \\
\text { dentatus }\end{array}$ & $\begin{array}{l}\text { Dark } \\
\text { reddish }\end{array}$ & $\begin{array}{l}\text { 3 angled } \\
\text { ovate }\end{array}$ & $1.9 \pm 0.02$ & $1.5 \pm 0.03$ & 1.3 & 2.9 & $719 \pm 5.2$ \\
\hline
\end{tabular}
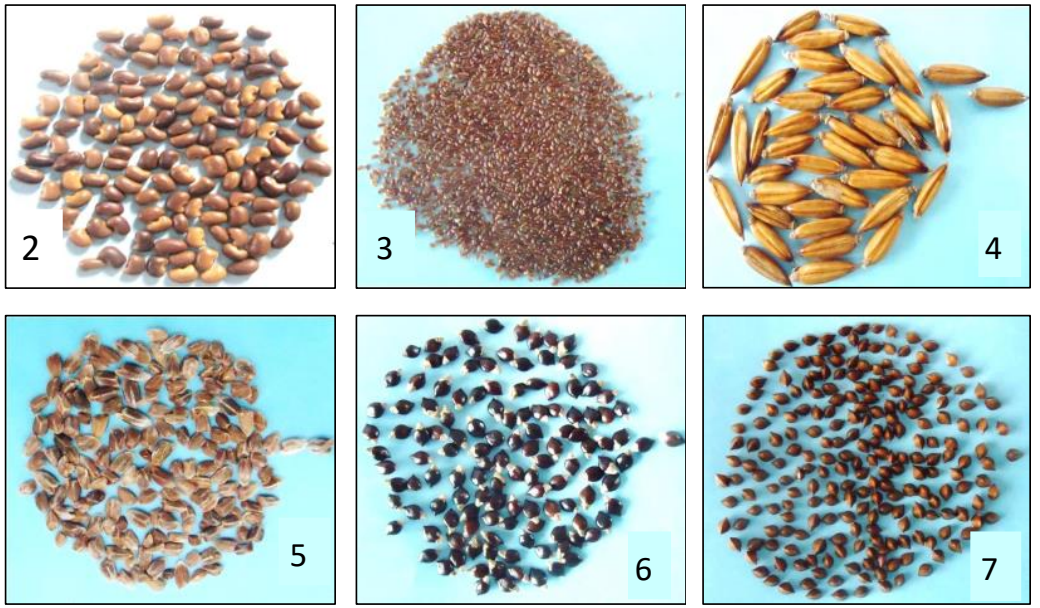

Figures: 2. seeds of Aeschynemone asper, 3. seeds of Eragrostis unioloides, 4. fruits of Hygrophila auriculata, 5. seeds of Hygrophila auriculata, 6. seeds of Persicaria barbatum, 7. seeds of Rumex dentatus. ( 1 = Germination, 2 = Vegetative phase, $3=$ Flowering, $4=$ Fruiting stage, $5=$ Seed maturation, $6=$ Senescent, $\mathrm{P}=$ Perennation, $*=$ Sprouting)

Seed viability, imbibition and germination of wetland plants at control condition are given in Table 2. Viable seeds of $A$. asper $(98 \%)$ and $P$. barbatum $(55 \%)$ had no germination at control in the laboratory. They may require certain precondition or treatment for germination. Panta (2016) reported up to $93 \%$ germination of $A$. asper by sulphuric acid scarification for 6 minute showing physical barrier in the seed coat. In the present study, 96\% germination occurred in $H$. auriculata, and Rumex dentatus while E. unioloides showed cent percent germination.

Table 2. Seed viability and germination of aquatic macrophytes in control.

\begin{tabular}{lccc}
\hline Species & Viability (\%) & Imbibition (\%) & Germination (\%) \\
\hline Aeschynemone asper & 98 & 1 & 0 \\
Eragrostis unioloides & 100 & 26 & 100 \\
Hygrophila auriculata & 93.3 & 252 & 96.7 \\
Pesicaria barbatum & 55 & 32 & 0 \\
Rumex dentatus & 96.7 & 22 & 96.7 \\
\hline
\end{tabular}




\section{Phenological behaviours}

Phenological observation of the wetland plants are given in Table 3 .

Table 3. Phenological observations in the form of phenograms of aquatic macrophytes at Biratnar, eastern Terai, Nepal.

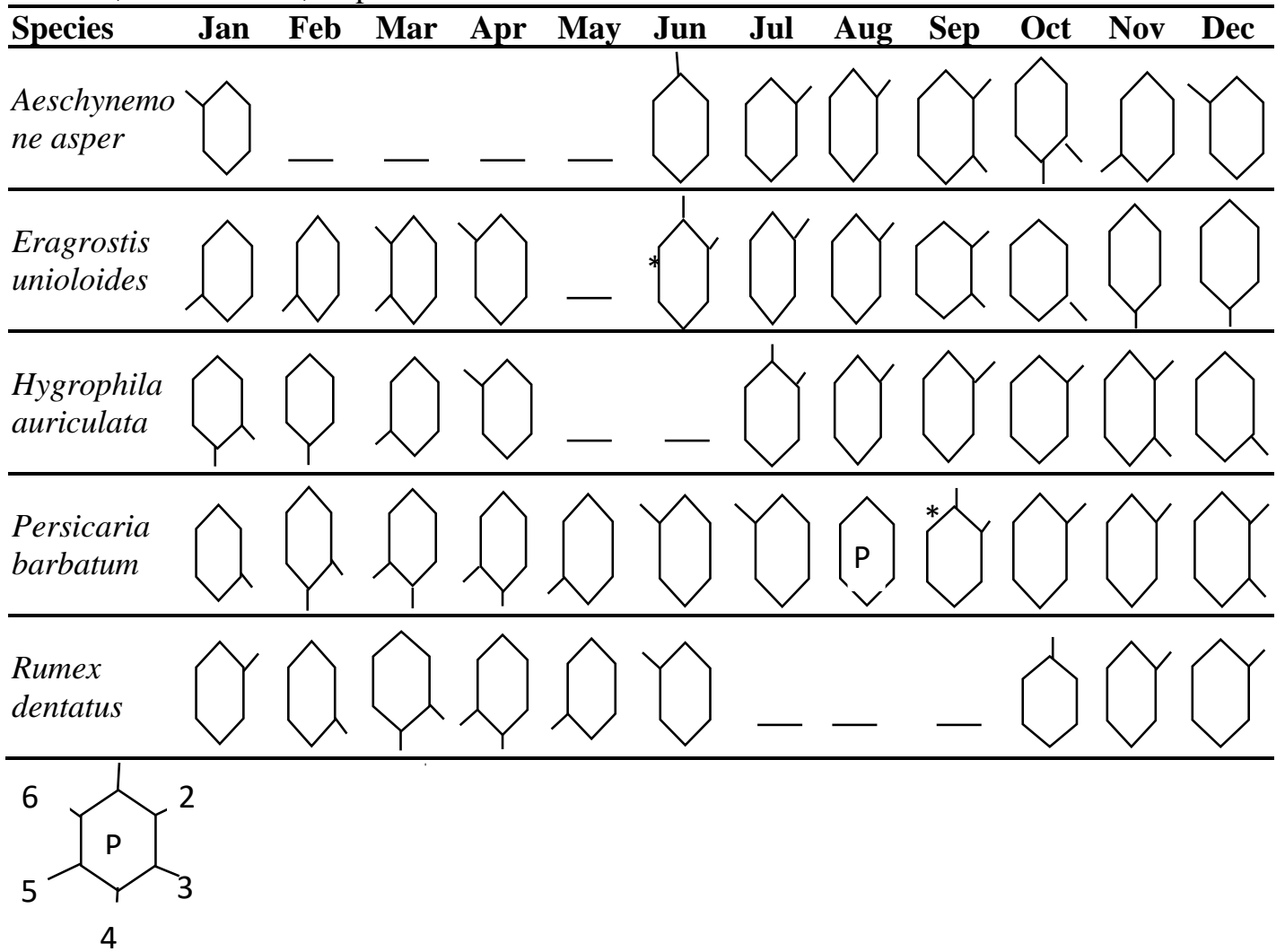

A. asper, E. unioloides and $H$. auriculata germinated in June and July before rainy season. Vegetative phase developed throughout rainy months and flowering in late rainy and winter seasons with decreasing day length of September (12 h 14min), October (11h $26 \mathrm{~min}$ ), November (10 $44 \mathrm{~min})$, December (10 h $32 \mathrm{~min}$ and January (10 h $32 \mathrm{~min})$. H. auriculata showed relatively long vegetative and flowering phases. P. barbatum and $R$. dentatus germinated/sprouted in late rainy season; vegetative growth occurred during winter months; flowering fruiting in early summer and senescent occurred in June-July. H. auriculata showed flowering during November-January; and fruiting from January and to February; seed maturation was in March, and senescence was marked in April in the present study.

Flowering time of aquatic macrophytes were maximum (60\%) during rainy and minimum $(15 \%)$ during summer but few species had flowering in all seasons. They flowered at the end of each season (Niroula, 2011). Wetland species of Nainital flowers only when the temperature rise (Purohit \& Singh, 1985). Aquatic macrophytes in the present observation flowered when temperature started to change. $P$. barbatum (summer annual) and $R$. dentatus (winter annual) showed germination in early winter (November- December) and vegetative growth throughout winter and early summer months (March-April). Rainy 
annuals (A. asper, E. unioloides, H. auriculata) germinated at the beginning of rainy and spent vegetative phase up to August - September, then started to flowering. Weeds of rice field germinated/emerged in early rainy months and completed their life cycle between July and October (Thapa \& Jha, 2002).

Gangory swmpy wetland plants of Uttarkashi (U.P.) Garhwal Himalaya shows their phonological behaviours at different times due to their unusual phenoplasticity (Lal et al., 1997). The sequence of phenophases in the tropics and subtropics with distinct rainy and dry seasons are linked to hydroperiodic alterations (Bertiller et al., 1990; Callow et al., 1992).

\section{Reference}

Bertiller, B., M. Monica, P. Jrisarri \& J.O. Ares. 1990. Phenology of Festeca palleseens in relation to topography in Northwestern Patagonia. J. Veg. Sci. 1(5): 579-585.

Bhandari, B. 2009. Wise use of wetlands in Nepal. IUCN, Nepal, Kathmandu. 9: 553-556.

Callow, J.M., H.A. Kantrud \& K.F. Higgins. 1992. First felowering dates and flowering period of Prairine plant at WoodWorth North Dacota. Prairine Nat. 24(20): 57-64.

Gasper, S. \& J. Nagy. 1998. A new method for tetrazolim analysis of wheat seeds without embryo excision. Seed Science and Technology 9: 553-556

IUCN/Nepal. 1992. Wetland management programme. A project document. IUCN/Nepal.

Lal, C., M. Kukret \& J.C. Ghildiyal. 1997. Preliminary phenological observation on some aquatic macrophytes of Gangori swampywetland, Uttarkashi, (U.P.) Garhwal Himalaya. J. Freshwater Biol. 9(3-4): 110-113.

Lodhiyal, L.S., S.P. Singh \& N. Lodhiyal. 1998. Phenology, population structure and dynamics of ringle bamboo (Arundinaria falcate) in Nainital hill of central Himalaya. Tropical Ecology 39: 109-115.

Mitch, W.J. \& J.G. Gooselink. 2000. Wetlands. John Wiley and Sons, Inc. New York.

Niroula, B. \& Kafle. 2016. Autecology of Mikania micrantha H.B.K.in Biratnagar, eastern Nepal. Vishleshan 13: 94-99.

Niroula, B. Ecology and phytosociology of aquatic macrophytes in and around Biratnagar, eastern Nepal. Ph. D. thesis, University Department of Botany, T.M. Bhagalpur University, Bhagalpur, India.

Panta, P. 2016. Phenology and seed germination behaviour of some aquatic macrophytes at Biratnagar, Nepal. M. Sc. thesis, Department of Botany, Post Graduate Campus, Tribhuvan University, Biratnagar, Nepal.

Paudel, S. 2016. Phenology and seed germination behaviour of some wetland plants of compositae family. M. Sc. thesis, Department of Botany, Post Graduate Campus, Tribhuvan University, Biratnagar, Nepal.

Purohit, R. \& S.P. Singh. 1985. Phenological observation of macrophytes of Nainital lake. Comp. Physiol. \& Ecology 10(4): 201-204.

Thapa, C.B. \& P.K. Jha. 2002. Ecophenology of weeds in paddy fields of Pokhara and Kathmandu. Ecoprint 9(1): 30-41.

Tiwari, S., B. Adhikary, M. Siwakoti \& K. Subedi. 2005. An inventory and assessment of invasive alien plant species of Nepal. IUCN, Nepal. 